\title{
Performance of Kerinci Ducks Treated by Cattle Rumen-Fluid Supernatant Addition as Source of Crude Enzyme in Rations
}

\author{
A. Budiansyah*, Resmi, Filawati, \& U. Haroen \\ Faculty of Animal Husbandry, University of Jambi, \\ Mendalo Darat Campus, Jalan Raya Jambi-Muara Bulian Km 15 Jambi, Indonesia \\ *Corresponding author: budiansyah_agus@yahoo.com \\ (Received 20-11-2019; Revised 17-02-2020; Accepted 06-03-2020)
}

\begin{abstract}
The objective of this study was to determine the effect of varying levels of cattle rumen fluid obtained from abattoirs as sources of a crude enzyme on growth performances and carcass characteristics of Kerinci ducks fed rations based on local feed ingredients. The research was carried out using 140 one-week-old male Kerinci ducks. The experiment used a randomized block design consisted of 5 treatments, each with 4 replicate groups and was blocked based on body weight, while each cage unit consisted of 7 ducks. The treatments applied were R1 $0 \mathbf{m L ~ R F S} / \mathrm{kg}$ ration (control), R2= R1 + $22 \mathrm{~mL} \mathrm{RFS} / \mathrm{kg}$ ration, $\mathrm{R} 3=\mathrm{R} 1+44 \mathrm{~mL} \mathrm{RFS} / \mathrm{kg}$ ration, $\mathrm{R} 4=\mathrm{R} 1+66 \mathrm{~mL} \mathrm{RFS} / \mathrm{kg}$ ration, and $\mathrm{R} 5=\mathrm{R} 1$ $+88 \mathrm{~mL} \mathrm{RFS} / \mathrm{kg}$ ration. The experimental ducks were fed the experimental ration for 7 weeks and fed ad libitum according to the treatment. At the end of the 7th weeks of treatment, two ducks from each cage were slaughtered and utilized for analysis of carcass and digestive organs parameters. The results showed that the addition of RFS up to a level of $88 \mathrm{~mL} / \mathrm{kg}$ ration had no significant effect ( $p>0.05$ ) on feed consumption, feed conversion, carcass weight, and digestive-organ weight. Still, it had significant effects on body weight gain and final body weight. The highest body weight gain and final body weight were achieved with the addition of RFS at the level of $88 \mathrm{~mL} / \mathrm{kg}$ ration. It can be concluded that the addition of cattle rumen-fluid supernatant as a source of crude enzymes at the level of $88 \mathrm{~mL} / \mathrm{kg}$ ration improved the growth performance of local Kerinci ducks.
\end{abstract}

Keywords: cattle rumen fluid; enzymes; local feed; duck performance; Kerinci duck

\section{INTRODUCTION}

The contents of the rumen in beef cattle, which are the wastes of a slaughterhouse, are quite abundant. If they are not handled properly, the rumen contents and rumen fluids have a great potential to pollute the environment. The results of previous studies prove that the wastes of rumen contents of slaughtered cows in slaughterhouses are rich in enzymes, especially carbohydrase, and proteases (Budiansyah et al., 2010; Rey et al., 2012; Vaithiyanathan et al., 2015). These enzymes have high activities with good enzyme characteristics that could be used as sources of enzymes to improve the quality of poultry feed (Budiansyah et al., 2010). The activities of enzymes in the rumen fluids of local dairy cows were shown to be $0.0487 \pm 0.0123 \mathrm{IU} / \mathrm{mL}$ for cellulase, 3.0200 $\pm 0.0797 \mathrm{IU} / \mathrm{mL}$ for amylase, $0.5086 \pm 0.0188 \mathrm{IU} / \mathrm{mL}$ for xylanase, $3.6500 \pm 1.1941 \mathrm{IU} / \mathrm{mL}$ for mannanase, 0.0177 $\pm 0.0069 \mathrm{IU} / \mathrm{mL}$ for protease, and $0.3559 \pm 0.1834 \mathrm{IU} / \mathrm{mL}$ for phytase. The activities of enzymes increased after the extraction by a precipitation method using ammonium sulfate salt, with 4.40 times increase for cellulase, 2.38 times increase for xylanase and mannanase, 1.61 times increase for amylase, 2.97 times increase for phytase, and 2.28 times increase for proteases (Budiansyah et al., 2010).
The existences of these enzymes cause the increases in the effectiveness of digestion and the efficiency of feed use in cattle that are higher than in poultry, especially with the use of high-fiber raw material in the feed. Budiansyah et al. (2011) reported that for some feed ingredients, namely for cassava leaves and palm kernel cakes, the enzymes found in the extracted rumen-fluid were able to increase the total levels of dissolved sugars resulting from the hydrolysis of non-starch carbohydrates (NSPs), with an increase of $55.97 \%$ and $6.15 \%$, respectively, with the addition of as much as $2.0 \%$ rumen-fluid enzymes of cattle. However, in rice bran, soybeans, and coconut cakes, the highest total dissolved sugar contents were obtained at the addition of rumenfluid enzyme at the level of $2.5 \%$, with the increases of $24.54 \%, 26.15 \%$, and $26.81 \%$, respectively.

In broilers, the high crude fiber content in rations have risks in reducing the growth rate and final body weight (Krás et al., 2013). However, the effects of highfiber diets in ducks have not been widely reported. Wang et al. (2017) reported that a high crude fiber content $(10.16 \%)$ in duck rations increased the growth rate. Still, the carcass weight was lower than that of ducks fed rations with low crude fiber content, and the weights of the digestive organs, such as the proventriculus and gizzard, were strongly influenced by the amount of 
crude fiber in the rations. Han et al. (2017) reported that the crude fiber content in duck rations did not affect the final body weight, but the optimal fiber content was $7.52 \%$.

Enzymes, such as cellulase, mannanase, xylanase, and several enzyme cocktails, have been used to increase the digestibility of high-fiber diets in poultry, thus increasing the utilization of energy. The utilization of rumen fluid of beef cattle obtained from slaughterhouses as a source of enzymes could be a solution to the use of low-quality poultry rations based on local feed by reducing the harmful effects of crude fiber.

This study aimed to determine the effect of varying levels of cattle rumen fluid obtained from abattoirs as sources of enzymes on growth performances and carcass characteristics of Kerinci ducks fed rations based on local feed ingredients.

\section{MATERIALS AND METHODS}

The rumen fluid was obtained from a slaughterhouse in the city of Jambi from the rumens of local Indonesian cattle (Bali cattle). The retrieval of rumen fluid was carried out every week for 7 weeks from 3-5 slaughtered cattle to prepare the sources of enzymes. The rumen fluid was taken immediately after slaughtering and filtered using two layers of filter cloth at $4^{\circ} \mathrm{C}$ to remove the solid particles. The solution was then taken to the laboratory directly under the cold conditions using an icebox. The fresh fluid was centrifuged at 5000 $\mathrm{g}$ and $4^{\circ} \mathrm{C}$ for 10 minutes. The supernatants were taken and used as sources of enzymes in the preparation of experimental diets. The rumen-fluid supernatant (RFS) was added to the rations by mixing evenly, and then the mixed feed was incubated for 24 hours, followed by drying in the sun for 24-48 hours. Calculation of the amount of cattle rumen-fluid supernatant as a source of enzymes was based on the calculations by Budiansyah et al. (2010) and Budiansyah et al. (2011).

The workflow of rumen fluid supernatant preparation and enzyme extraction from cattle rumen fluid collected from a slaughterhouse are presented in Figure 1. The iso-calory and iso-protein experimental diets were made weekly based on the requirement of the ducks during the starting (0-4 weeks) and finishing (5-8 weeks) periods according to the NRC (1994) using local feed ingredients, including rice bran, yellow corn, soybean meal, fish meal, and palm kernel cake meal, as well as the other ingredients, such as mineral mix and premix. The composition of feed ingredients and dietary nutrient contents of the experimental rations are presented in Table 1. The dietary treatments were as follows: R1 was ration without RFS (control, equivalent to the addition of $0 \%$ of the enzymes extracted from cattle rumen-fluid),

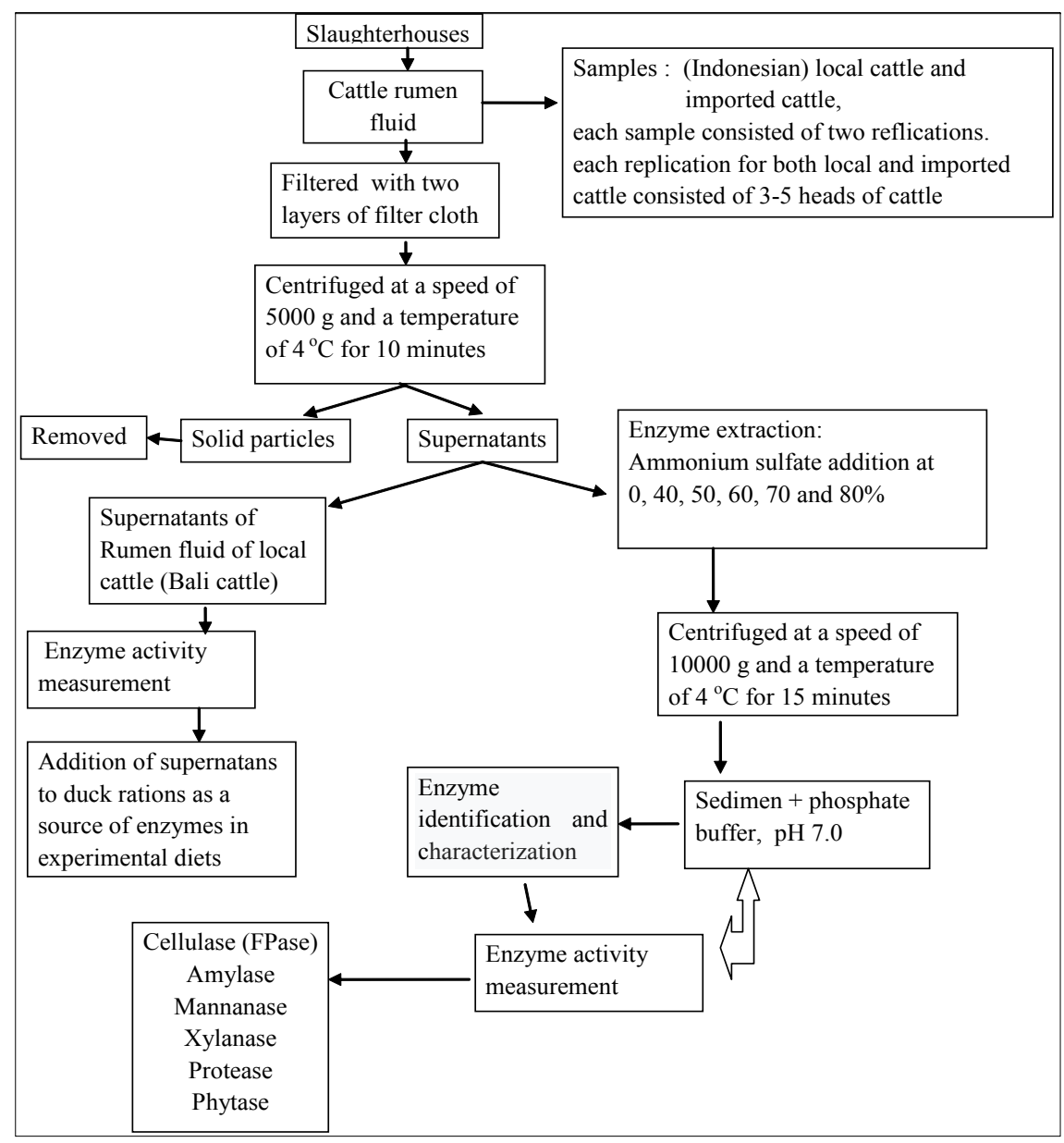

Figure 1. Workflow of enzyme preparation and extraction from cattle rumen fluid obtained from a slaughterhouse (based on Budiansyah et al., 2010 and Budiansyah et al., 2011). 
R2 was R1 with $22 \mathrm{~mL}$ RFS per $\mathrm{kg}$ ration (equivalent to the addition of $0.5 \%$ extracted enzymes), R3 was R1 with $44 \mathrm{~mL}$ RFS per $\mathrm{kg}$ ration (equivalent to the addition of $1.0 \%$ extracted enzymes), R4 was R1 with $66 \mathrm{~mL}$ RFS per $\mathrm{kg}$ ration (equivalent to the addition of $1.5 \%$ extracted enzymes), and R5 was R1 with $88 \mathrm{~mL} \mathrm{RFS/kg}$ ration (equivalent to the addition of $2.0 \%$ extracted enzymes).

A total of 140 one-week-old male ducks (local Kerinci) were used in this study. Each treatment was divided into 4 replicate groups, and each group consisted of 7 birds. The division into groups of body weights was carried out with intervals of duck body weight per bird that were less than or equal to $54 \mathrm{~g}$ for the 1st group, 55 to $61 \mathrm{~g}$ for the 2nd group, 62 to $83 \mathrm{~g}$ for the 3rd group, and greater than or equal to $84 \mathrm{~g}$ per bird for the 4 th group. Ducks were maintained for 7 (seven) weeks with ad libitum access to the treatment diets and drinking water. At the end of 7 weeks, two birds with body weights that approached the average weight of each cage were slaughtered for carcass and digestive organs analysis. The ducks were fasted for 12 hours and were slaughtered by cutting off their jugular veins.

The observed variables were feed consumption, body weight gain, and feed conversion, carcass weight, and the weight of the digestive organs (proventriculus, gizzard, pancreas, small intestine, and large intestine) of the experimental ducks. The final body weights were measured at the end of the experiment when the ducks were 8 weeks old. The body weight gain was calculated by subtracting the final body weight with the initial body weight and dividing it by the number of weeks of the experiment. Feed consumption was taken as the difference between the quantity of feed given previously and the number of refusals. The body weight gain and feed consumption were used to calculate the feed conversion ratio, which was calculated by dividing the feed consumption by the bodyweight gain.

Carcass weights were obtained from the slaughtered ducks, the feathers, head, and feet were removed, and the heart, liver, and digestive organs, except the kidney and lung, were removed. Carcass weight was calculated as a percentage of the live body weight. The contents of the intestine were removed, and the empty weights of the small intestine (from the pancreatic loop to the ileocecal junction) and the large intestine (caecum and colon) were measured. The pancreas, proventriculus, gizzard, small intestine, and large intestine were weighed. The traits of all of these organs were calculated as percentages relative to the live body weight.

The design of the experiment was a randomized block design, and a two-way ANOVA was performed on the observed variables. Duncan's multiple range test was conducted to analyze the difference of treatments (Steel \& Torrie, 1980).

Table 1. The composition (\%) and nutrient content of the experimental diets

\begin{tabular}{|c|c|c|c|c|c|c|c|c|c|c|}
\hline \multirow{2}{*}{ Ingredient } & \multicolumn{5}{|c|}{ Starting phase } & \multicolumn{5}{|c|}{ Finishing phase } \\
\hline & R1 & $\mathrm{R} 2$ & R3 & $\mathrm{R} 4$ & R5 & R1 & $\mathrm{R} 2$ & R3 & $\mathrm{R} 4$ & R5 \\
\hline Corn, $(\%)$ & 38 & 38 & 38 & 38 & 38 & 47.5 & 47.5 & 47.5 & 47.5 & 47.5 \\
\hline Rice bran, $(\%)$ & 7 & 7 & 7 & 7 & 7 & 8 & 8 & 8 & 8 & 8 \\
\hline Soybean meal, (\%) & 25 & 25 & 25 & 25 & 25 & 19.5 & 19.5 & 19.5 & 19.5 & 19.5 \\
\hline Fish meal, (\%) & 9 & 9 & 9 & 9 & 9 & 5 & 5 & 5 & 5 & 5 \\
\hline Palm kernel cake meal, (\%) & 14 & 14 & 14 & 14 & 14 & 14 & 14 & 14 & 14 & 14 \\
\hline Palm oil, (\%) & 5 & 5 & 5 & 5 & 5 & 4 & 4 & 4 & 4 & 4 \\
\hline Mineral mix $(\%)^{1)}$ & 1 & 1 & 1 & 1 & 1 & 1 & 1 & 1 & 1 & 1 \\
\hline Premix, $(\%)^{2)}$ & 1 & 1 & 1 & 1 & 1 & 1 & 1 & 1 & 1 & 1 \\
\hline Total, $(\%)$ & 100 & 100 & 100 & 100 & 100 & 100 & 100 & 100 & 100 & 100 \\
\hline Rumen fluid supernatant, $(\mathrm{mL} / \mathrm{kg})$ & 0 & 22 & 44 & 66 & 88 & 0 & 22 & 44 & 66 & 88 \\
\hline \multicolumn{11}{|l|}{ Calculated nutrient content, } \\
\hline Metabolizable energy, (Kcal/kg) & 2920.06 & 2920.06 & 2920.06 & 2920.06 & 2920.06 & 2924.11 & 2924.11 & 2924.11 & 2924.11 & 2924.11 \\
\hline Crude protein, $(\%)$ & 22.01 & 22.01 & 22.01 & 22.01 & 22.01 & 18.13 & 18.13 & 18.13 & 18.13 & 18.13 \\
\hline Crude fat, $(\%)$ & 8.66 & 8.66 & 8.66 & 8.66 & 8.66 & 7.41 & 7.41 & 7.41 & 7.41 & 7.41 \\
\hline Crude fiber, $(\%)$ & 6.75 & 6.75 & 6.75 & 6.75 & 6.75 & 6.72 & 6.72 & 6.72 & 6.72 & 6.72 \\
\hline Ash, (\%) & 5.61 & 5.61 & 5.61 & 5.61 & 5.61 & 4.54 & 4.54 & 4.54 & 4.54 & 4.54 \\
\hline Calcium (Ca), $(\%)$ & 0.97 & 0.97 & 0.97 & 0.97 & 0.97 & 0.79 & 0.79 & 0.79 & 0.79 & 0.79 \\
\hline Phosphorus (P), (\%) & 0.65 & 0.65 & 0.65 & 0.65 & 0.65 & 0.54 & 0.54 & 0.54 & 0.54 & 0.54 \\
\hline
\end{tabular}

Note: R1= ration without RFS (control, equivalent to the addition of $0 \%$ of the enzymes extracted from cattle rumen-fluid), R2= R1 with $22 \mathrm{~mL}$ RFS per $\mathrm{kg}$ ration (equivalent to the addition of $0.5 \%$ extracted enzymes), R3= R1 with $44 \mathrm{~mL}$ RFS per $\mathrm{kg}$ ration (equivalent to the addition of $1.0 \%$ extracted enzymes), R4= R1 with $66 \mathrm{~mL}$ RFS per $\mathrm{kg}$ ration (equivalent to the addition of $1.5 \%$ extracted enzymes), R5= R1 with $88 \mathrm{~mL}$ RFS/kg ration (equivalent to the addition of $2.0 \%$ extracted enzymes).

1) The "MINERAL FEED SUPPLEMENT" contained the following per $1 \mathrm{~kg}$ : calcium (Ca), 32.5\%; phosphorous (P), $1.0 \%$; iron (Fe), 6 g; manganese (Mn), 4 g; iodine (I), 0.075 g; copper, (Cu) 0.3 g; zinc (Zn), 3.75 g; vitamin B12, 0.5 mg; and vitamin D3, 50,000 IU.

2) The "Top Mix" premix contained the following per $10 \mathrm{~kg}$ : vitamin A, 12,000,000 IU; vitamin D3, 2,000,000 IU; vitamin E, 8,000 IU; vitamin K, 2,000 mg; vitamin B1, 2,000 mg; vitamin B2, 5,000 mg; vitamin B6, 500 mg; vitamin B12, 12,000 g; vitamin C, 25,000 mg; calcium-D-pantothenate, 6,000 mg; niacin, 40,000 mg; choline chloride, $10,000 \mathrm{mg}$; methionine, 30,000 mg; lysine, 30,000 mg; manganese, $120,000 \mathrm{mg}$; iron, $20,000 \mathrm{mg}$; iodine, $200 \mathrm{mg}$; zinc, 100,000 mg; cobalt, $200 \mathrm{mg}$; copper, 4,000 mg; zinc bacitracin, 21,000 mg; and excipient q.s., 10,000 mg. 


\section{RESULTS}

\section{Growth Performances}

The effects of RFS treatment on the performances of male Kerinci ducks are presented in Table 2. The results showed that the treatment of several levels of RFS as an enzyme source in the Kerinci duck ration based on local feedstuffs had no significant effects on the feed consumption and feed conversion ratio. In contrast, the level of RFS in the ration had a significant effect on body weight gain and final body weight $(\mathrm{p}<0.05)$. Feed consumptions of ducks fed rations supplemented with RFS at levels of $0 \mathrm{~mL} / \mathrm{kg}$ ration (R1), $22 \mathrm{~mL} / \mathrm{kg}$ ration (R2), $44 \mathrm{~mL} / \mathrm{kg}$ ration (R3), $66 \mathrm{~mL} / \mathrm{kg}$ ration $(\mathrm{R} 4)$, and 88 $\mathrm{mL} / \mathrm{kg}$ ration (R5) were not significantly different. The consumption of rations ranged from $3398 \pm 355 \mathrm{~g} / \mathrm{bird} / 7$ weeks in the R3 group to $3893 \pm 826 \mathrm{~g} / \mathrm{bird} / 7$ weeks in the R1 group.

The supplementations of RFS significantly affected $(p<0.05)$ the total body weight gains and final body weights, while the feed conversion ratios were not affected by the levels of RFS in the ration. Ducks fed rations supplemented with RFS at the level of $88 \mathrm{~mL} /$ $\mathrm{kg}$ (R5) showed a significantly higher body weight gain than the ducks fed rations supplemented with the other levels of RFS treatments. However, the feed conversion efficiency was not affected by RFS supplementation in the ration.

The results showed that the RFS treatment had no significant effect on the percentages of carcass weights of experimental ducks. The average relative carcass weight (percentage of carcass weight) of local, male, Kerinci ducks at 8 weeks of age ranged from $61.67 \pm$ $6.71 \%$ to $64.43 \pm 2.54 \%$.

\section{Weight of Digestive Organs}

The effects of RFS treatment on the relative weight of the digestive organs of male Kerinci ducks are presented in Table 3. The RFS treatment had no significant effect on the relative weights of the digestive organs of male Kerinci ducks, specifically, the proventriculus, gizzard, small intestine, pancreas, and large intestine. The percentages of the weights of these organs to the carcass weight ranged from $0.40 \pm 0.04 \%$ to $0.46 \pm 0.03 \%$ for the proventriculus, $5.61 \pm 0.33 \%$ to $6.12 \pm 0.66 \%$ for the gizzard, $1.47 \pm 0.16 \%$ to $1.64 \pm 0.41 \%$ for the small intestine, $0.38 \pm 0.11 \%$ to $0.51 \pm 0.08 \%$ for the pancreas, and $1.06 \pm$ $0.14 \%$ to $1.33 \pm 0.24 \%$ for the large intestine.

\section{DISCUSSION}

\section{Duck Performances}

The results showed that feed consumption did not differ between treatments, suggesting that RFS did not affect the palatability of the experimental diets. The results of this study exhibited the lower feed consumption rates than those reported by Attia et al. (2019) that White Pekin ducks consumed approximately $6202 \mathrm{~g} / \mathrm{bird}$ for 8 weeks. Iriyanti et al. (2018) reported that the average consumption of ration for Tegal ducks ranged from $101.45 \pm 2.45$ to $104.14 \pm 2.75 \mathrm{~g} / \mathrm{bird} / \mathrm{day}$, equivalent to 5839 to $5929 \mathrm{~g} / \mathrm{bird}$ for 8 weeks. These results were suspected due to the differences in the composition of feed ingredients, preparation of rations and nutrient content, as well as the effect of breed differences. In this study, the growth rate was lower, with lower final body weight than those reported by Attia et al. (2019) and Iriyanti et al. (2018) for Pekin ducks.

The addition of rumen-fluid supernatant of cattle at $88 \mathrm{~mL} / \mathrm{kg}$ ration (R5) significantly improved the per-

Table 2. Performance of Kerinci ducks treated with rumen-fluid supernatant (RFS) as a source of enzymes

\begin{tabular}{lccccc}
\hline \multirow{2}{*}{\multicolumn{1}{c}{ Variables }} & \multicolumn{4}{c}{ Level of cattle rumen fluid addition in the duck rations } \\
\cline { 2 - 6 } & $0 \mathrm{~mL} / \mathrm{kg}(\mathrm{R} 1)$ & $22 \mathrm{~mL} / \mathrm{kg}(\mathrm{R} 2)$ & $44 \mathrm{~mL} / \mathrm{kg}(\mathrm{R} 3)$ & $66 \mathrm{~mL} / \mathrm{kg}(\mathrm{R} 4)$ & $88 \mathrm{~mL} / \mathrm{kg}(\mathrm{R} 5)$ \\
\hline Initial body weight $(\mathrm{g} / \mathrm{bird})$ & $72.36 \pm 28.85^{\mathrm{a}}$ & $67.57 \pm 20.05^{\mathrm{a}}$ & $65.11 \pm 17.44^{\mathrm{a}}$ & $71.14 \pm 28.88^{\mathrm{a}}$ & $69.64 \pm 22.57^{\mathrm{a}}$ \\
Feed consumption (g/bird/7 weeks) & $3892.67 \pm 825.60^{\mathrm{a}}$ & $3550.92 \pm 716.26^{\mathrm{a}}$ & $3398.45 \pm 355.49^{\mathrm{a}}$ & $3857.47 \pm 565.84^{\mathrm{a}}$ & $3711.47 \pm 811.91^{\mathrm{a}}$ \\
Body weight gain (g/bird/7 weeks) & $821.27 \pm 78.55^{\mathrm{a}}$ & $831.72 \pm 59.50^{\mathrm{ab}}$ & $882.10 \pm 66.70^{\mathrm{ab}}$ & $888.75 \pm 66.82^{\mathrm{ab}}$ & $917.25 \pm 55.29^{\mathrm{b}}$ \\
Feed conversion ratio & $4.702 \pm 0.550^{\mathrm{a}}$ & $4.244 \pm 0.558^{\mathrm{a}}$ & $3.848 \pm 0.158^{\mathrm{a}}$ & $4.351 \pm 0.673^{\mathrm{a}}$ & $4.043 \pm 0.853^{\mathrm{a}}$ \\
Final body weight (g/bird) & $893.62 \pm 54.22^{\mathrm{a}}$ & $899.32 \pm 48.34^{\mathrm{a}}$ & $947.22 \pm 54.58^{\mathrm{ab}}$ & $959.92 \pm 41.41^{\mathrm{ab}}$ & $986.87 \pm 46.47^{\mathrm{b}}$ \\
Carcass weight (\%) & $64.43 \pm 2.54^{\mathrm{a}}$ & $62.52 \pm 1.26^{\mathrm{a}}$ & $63.22 \pm 4.25^{\mathrm{a}}$ & $61.73 \pm 3.34^{\mathrm{a}}$ & $61.67 \pm 6.71^{\mathrm{a}}$ \\
\hline
\end{tabular}

Note: means in the same row with different superscripts differ significantly $(\mathrm{p}<0.05)$.

Table 3. The digestive organ weight of local Kerinci ducks treated with rumen-fluid supernatant (RFS) as a source of enzymes

\begin{tabular}{lccccc}
\hline \multirow{2}{*}{\multicolumn{1}{c}{ Variables }} & \multicolumn{5}{c}{ Level of cattle rumen fluid addition in the duck rations } \\
\cline { 2 - 6 } & $0 \mathrm{~mL} / \mathrm{kg}(\mathrm{R} 1)$ & $22 \mathrm{~mL} / \mathrm{kg}(\mathrm{R} 2)$ & $44 \mathrm{~mL} / \mathrm{kg}(\mathrm{R} 3)$ & $66 \mathrm{~mL} / \mathrm{kg}(\mathrm{R} 4)$ & $88 \mathrm{~mL} / \mathrm{kg}(\mathrm{R} 5)$ \\
\hline Gizzard (\% of live body weight, LBW) & $5.67 \pm 0.35$ & $6.12 \pm 0.66$ & $5.57 \pm 0.31$ & $5.61 \pm 0.33$ & $5.71 \pm 0.47$ \\
Proventriculus (\%LBW) & $0.46 \pm 0.03$ & $0.41 \pm 0.02$ & $0.45 \pm 0.09$ & $0.40 \pm 0.04$ & $0.43 \pm 0.07$ \\
Pancreas (\%LBW) & $0.38 \pm 0.11$ & $0.51 \pm 0.08$ & $0.46 \pm 0.06$ & $0.49 \pm 0.11$ & $0.39 \pm 0.03$ \\
Small intestine (\%LBW) & $1.47 \pm 0.16$ & $1.64 \pm 0.41$ & $1.58 \pm 0.19$ & $1.54 \pm 0.10$ & $1.49 \pm 0.11$ \\
Large intestine (\%LBW) & $1.33 \pm 0.24$ & $1.06 \pm 0.14$ & $1.21 \pm 0.23$ & $1.13 \pm 0.19$ & $1.15 \pm 0.25$ \\
\hline
\end{tabular}


formance of Kerinci ducks by increasing body weight gain and final body weight. It was suspected that the addition of cattle rumen fluid as a source of enzymes could slightly improve the quality of rations of ducks. Budiansyah et al. (2011) reported that the addition of rumen fluid enzymes at the level of $1 \%$ to the rations of starter and finisher broilers increased the total levels of dissolved sugars derived from the hydrolysis of non-starch carbohydrates by $22.06 \%$ and $15.30 \%$, respectively. The feed conversion ratio tended to be similar among the treatments of different levels of RFS, showing that there was no improvement in the feed conversion efficiency. These results are similar to those reported by Kang et al. (2013) that supplementation with complex enzymes at the levels of 0.5 and $1.0 \mathrm{~g} / \mathrm{kg}$ ration $(0.05 \%$ and $0.1 \%)$ consisting of xylanase, $\beta$-glucanase, and cellulase enzymes, in corn, rice, and soybean mealbased rations, increased body weight gain, reduced feed consumption, and increased feed digestibility in Cherry Valley broiler ducks. A similar result of the improved performance of Cherry Valley broiler ducks was reported by Zeng et al. (2015) with addition of the enzyme complex Ravabio containing xylanase, beta glucanase, and phytase in the ration. Purba \& Sinurat (2018) reported that BS4 enzyme supplementation (150 units $/ \mathrm{kg}$ ) in $30 \%$ rice bran-based rations gave the best results to support the best growth of PMp (a cross between male Pekin ducks and female white Mojosari ducks) broiler ducks during the first 4 weeks of maintenance. They showed the lowest average feed consumption of $998 \mathrm{~g} /$ bird and the lowest feed conversion of 2.64; however, the observation had no significant effect on body weight gain.

Biyatmoko \& Rostini (2016) reported that supplementation of protease enzyme at the level of $0.15 \%$ in rations substantially improved the performance of egg production in Alabio duck. Those researches showed the egg production rate increased from $66.11 \%$ to $83.51 \%$ hen-day production, the egg weight increased from $62.22 \mathrm{~g} / \mathrm{egg}$ to $64.36 \mathrm{~g} / \mathrm{egg}$, and the feed conversion ratio (FCR) decreased from 3.50 to 3.01. Rui et al. (2012) reported that enzyme supplementation stimulated the increased activity of endogenous enzymes in the digestive tract of ducks in the early growth phases, namely, pepsin in the proventriculus at 3 weeks of age and trypsinase at 3 to 4 weeks, and lipase at 2 to 3 weeks in the pancreas.

The results of these studies indicated that the addition of both individual enzymes or multiple enzymes in feed-based rations containing a high quantity of non-starch polysaccharides had a positive effect on the duck performance, as was reported by some researchers on broiler chickens (Akyurek et al., 2009; Gitoee et al., 2014; Goli \& Shahryar, 2015; Moss et al., 2017; Teymouri et al., 2018; Effiong et al., 2019). The improvement in performance was thought to be due to an increase in the digestibility of food substances, including crude protein, crude fiber, and ash (minerals) (Kang et al., 2013; Zeng et al., 2015; Moss et al., 2017; Effiong et al., 2019) and a decrease in the viscosity of gastrointestinal digesta (Moftakharzadeh et al., 2017; Teymouri et al., 2018).
The average carcass percentage of male Kerinci ducks at 8 weeks of age ranged from $61.67 \pm 6.71 \%$ to $64.43 \pm 2.54 \%$. These findings were higher than those obtained by Iriyanti et al. (2018) for Tegal ducks, which ranged from $57.14 \pm 3.52 \%$ to $59.55 \pm 1.99 \%$, but they were similar to the results obtained by Attia et al. (2019) for White Pekin ducks, which ranged from $64.4 \%$ to $66.6 \%$. The results showed that the RFS treatment had no significant effect on the percentage of carcass weight in ducks. The results suggested that the percentage of carcass weight in ducks directly depends on the performance of the body weight.

Studies on the effect of the addition of enzymes in duck rations on carcass weights are scarce, but similar studies on broiler chickens have been widely reported with mixed results. Goli \& Shahryar (2015) and Teymouri et al. (2018) reported that the addition of enzymes (multiple enzymes) to the rations of broiler chickens did not affect the percentage of carcass weight, although the body weight increased with the addition of enzymes. However, Attia et al. (2014) found that the addition of multiple enzymes increased the percentage of carcass weight and total edible parts of broiler chickens. The increase in the percentage of carcass weight was due to a decrease in the inedible parts of broiler chickens and the weight of the small intestine (Moftakharzadeh et al., 2017).

\section{Weight of Digestive Organ}

The weight percentages of digestive organ to live weight were $0.40 \pm 0.04 \%$ to $0.46 \pm 0.03 \%$ for the proventriculus, $5.61 \pm 0.33 \%$ to $6.12 \pm 0.66 \%$ for the gizzard, $1.47 \pm 0.16 \%$ to $1.64 \pm 0.41 \%$ for the small intestine, $0.38 \pm$ $0.11 \%$ to $0.51 \pm 0.08 \%$ for the pancreas, and $1.06 \pm 0.14 \%$ to $1.33 \pm 0.24 \%$ for the large intestine. Iriyanti et al. (2018) found that the weight percentages of the small intestine, gizzard, crop, and pancreas were $3.34 \pm 0.27 \%-4.04 \pm$ $0.65 \%, 3.91 \pm 0.51 \%-4.97 \pm 0.24 \%, 3.46 \pm 0.40 \%-4.45 \pm$ $0.29 \%$, and $0.37 \pm 0.02 \%-0.40 \pm 0.04 \%$, respectively. The results of this study indicated that the percentage of the small intestine weight was lower than that obtained by Iriyanti et al. (2018), who reported a higher percentage of gizzard weight, whereas the pancreas was relatively similar. This difference might be due to the different types of duck and feed or ration used. Wasilewski et al. (2015) reported that the weight percentages of digestive organs in Peking duck depends on gender and genetics.

The results showed that the RFS treatment had no significant effect $(p>0.05)$ on the relative weights of the digestive organs of local Kerinci ducks. These results indicated that the addition of enzymes derived from the rumen fluid of cattle did not affect the size of these organs. It was thought that rumen fluid enzymes do not directly affect the size and weight of digestive organs because the enzymes function to hydrolyze complex compounds into simpler substances so that the weights of the digestive organs produced are relatively similar among treatments. Wang et al. (2017) reported that the crude fiber content of rations was very influential on the weights and sizes of the digestive organs of local 
Chinese ducks. A higher crude fiber content in the rations resulted in a higher percentage of the proventricular and gizzard weights, while the percentage of small intestine weight (jejunum and ileum) decreased, and those of the duodenum and pancreas were not significantly different. The results of proventricular weights showed that the addition of rumen fluid from cattle as a source of enzymes in duck rations had no significant effect on the relative weight of the proventriculus. The proventriculus, also called the glandular stomach, works to secrete digestive enzymes in the form of $\mathrm{HCl}$ and pepsin in ducks and is more active than that in chickens (Adeola, 2006). Hajati et al. (2009) used multiple enzymes (cellulase, hemicellulase, protease, alphaamylase, and alpha-galactosidase) and Teymouri et al. (2018) used an enzyme cocktail containing $\beta$-glucanase, xylanase, and cellulase in broiler rations, and both reported no significant effect on proventricular weight. However, Zhu et al. (2014) reported that the relative weight of the proventriculus would not change significantly due to the addition of carbohydrase enzymes in broiler rations during the first 14 days and would be significantly different after the age of 21 days. This difference was due to the increased enzyme secretion caused by the increased viscosity of digesta in the digestive tract. The higher the crude fiber content of rations, the higher the viscosity of the digesta will be, thereby increasing the weight of the proventriculus (Wang et al., 2017).

The results on gizzard weights showed that the addition of cattle rumen fluid as a source of enzymes in Kerinci duck rations did not significantly affect the relative weight of gizzards. These results are the same as those reported by Zhu et al. (2014), Hajati et al. (2009), Moftakharzadeh et al. (2017), and Teymouri et al. (2018). The gizzard works to grind food, reduce its particle size, and increase the surface area of food (Adeola, 2006) so that when the food enters the small intestine, it is in the form of a paste. Therefore, rough foods with high crude fiber content will increase the workload of the gizzard. Wang et al. (2017) reported that the higher the crude fiber content of a ration, the greater the weight of the gizzard will be. The results of this research on the weights of the small intestine and large intestine showed that the addition of rumen fluid from cattle in slaughterhouses as a source of enzymes in Kerinci duck rations had no significant effect on the relative weights of the small intestine and large intestine.

The insignificant weight changes for the small intestine and large intestine showed that the addition of rumen fluid enzymes had little effect on the weight of the digestive tract. This also indicated that the weights of the small intestine, comprising the duodenum, jejunum, and ileum, followed the trend of body weight; the higher the body weight, the longer the small intestine will be. Shahir et al. (2013) reported that the addition of enzymes to feed did not significantly change the weights of the duodenum, jejunum, ileum, and caeca but significantly decreased the lengths of the duodenum and jejunum. The results above were different from those of Moftakharzadeh et al. (2017), who reported that the addition of $\beta$-glucanase and xylanase enzymes to barley-based rations reduced the weights of the duodenum, jejunum, ileum, and cecum but did not significantly decrease the lengths of portions of the small intestine. Akyurek et al. (2009) also reported that in addition to reducing the relative lengths of the duodenum, jejunum, ileum, and cecum, it also reduced the weights of these parts. The decrease in the length and weight of the digestive tract was caused by the increased digestive activity of exogenous enzymes and was related to the decrease in the viscosity of digesta and the rapid rate of nutrients digestion.

In the small intestine, food is digested with the help of an enzyme secreted by the pancreas and absorbed through the villi of the small intestine. Carbohydrates instead of starch could increase the viscosity of the digesta and prevent the effective contact between the substrate and the digestive enzymes, which could lead to noticeable changes in the structures and functions of the intestine and organs. The secretion of the gastrointestinal enzyme could be increased to adjust the changes that occur due to the presence of these compounds (Shahir et al., 2013). Therefore, these results can affect the weights of digestive tract components, such as the proventriculus, gizzard, small intestine, pancreas, large intestine, and liver, as an adaptive response to the increased enzyme requirements. Wang et al. (2017) reported that the fiber content of rations significantly decreased the weights of the small intestine (the jejunum and ileum), while the weights of the proventriculus and gizzard increased, and the weight of the duodenum was not significantly different with different fiber contents.

The results of the weight of the pancreas in this study showed that the addition of rumen fluid from cattle slaughterhouses as a source of enzymes in the diet of local ducks based on local feed did not significantly affect the relative weight of the pancreas. These results were similar to those reported by Shahir et al. (2013), Zhu et al. (2014), and Attia et al. (2019) for pancreatic weights. Moftakharzadeh et al. (2017) reported that the addition of $\beta$-glucanase and xylanase enzymes in barley-based rations reduced the weight of the pancreas of broiler chickens. The same result was reported by Teymouri et al. (2018) in broiler chickens with the supplementation of enzyme cocktails containing $\beta$-glucanase, xylanase, and cellulase in a hulless barley ration, which reduced the weight of the pancreas. The decrease in pancreatic weight is thought to be caused by the secretion of endogenous amylase, which is reduced by the pancreas due to exogenous amylase and related to the decrease in digesta viscosity and the rapid digestion of nutrients (Moftakharzadeh et al., 2017). Rui et al. (2012) reported that supplementation with xylanase, mannanase, and $\beta$-glucanase enzymes decreased the activity of pancreatic amylopsin enzymes in ducks at the ages of 14 and 42 days. The function of the pancreas is to produce and secrete amylase, trypsin, chymotrypsin, elastase, carboxypeptidase, lipase, and cholesterol esterase enzymes to hydrolyze starch, fat, and protein (Adeola, 2006) but do not produce fiber-digesting enzymes. The results of this study did not differ significantly in terms of the pancreas weight likely because the ration used was high in non-starch polysaccharides; 
thus, the digestive process required more fiber-digesting enzymes, such as cellulase, xylanase or mannanase, that are not produced by the poultry, so it was possible that the secretion of endogenous amylase by the pancreas did not change much.

\section{CONCLUSION}

The addition of RFS obtained from an abattoir at a level of $88 \mathrm{~mL} / \mathrm{g}$ (equivalent to the addition of $2.0 \%$ extracted enzymes from the rumen fluid of cattle) in the ration of local Kerinci ducks slightly improved their performances by increasing the body weight gain and final body weight.

\section{CONFLICT OF INTEREST}

The authors of this work declare no financial conflicts of interest or relationships with people or organizations that could inappropriately influence or introduce bias to the contents of this paper.

\section{ACKNOWLEDGEMENT}

The authors would like to thank the Rector of Jambi University and the Head of Research and Community Services Institute of Jambi University for providing funds for this research.

\section{REFERENCES}

Adeola, O. 2006. Review of research in duck nutrient utilization. Int. J. Poult.Sci. 5:201-218. https://doi.org/10.3923/ ijps.2006.201.218

Akyurek, H., A. A. Okur, \& H. E. Samli. 2009. Impact of phytase and/or carbohydrases on performance, intestinal organs and bone development in broiler fed wheat-based diets containing different levels of phosphorus. J. Anim. Vet. Adv. 8:1432-1437.

Attia, Y. A., N. F. Addeo, A. A. H. E. A. Al-Hamid, \& F. Bovera. 2019. Effects of phytase supplementation to diets with or without zinc addition on growth performance and zinc utilization of white pekin ducks. Animals 9:1-12. https:// doi.org/10.3390/ani9050280

Attia, Y.A., W. S. El-Tahawy, Abd El-Hamid E. Abd ElHamid, A. Nizza, M. A. Al-Harthi, M. I. El-Kelway, \& F. Bovera, 2014. Effect of feed form, pellet diameter and enzymes supplementation on carcass characteristics, meat quality, blood plasma constituents and stress indicators of broilers. Archiv Tierzucht 57: 1-14. https://doi. org/10.7482/0003-9438-57-030

Biyatmoko, D. \& T. Rostini. 2016. The effect of protease enzyme supplementation to productivity eggs of alabio duck. Int. J. Biosci. 8:203-208. https://doi.org/10.12692/ijb/8.2.202-208

Budiansyah, A., Resmi, Nahrowi, K. G. Wiryawan, M. T. Soehartono, \& Y. Widyastuti. 2011. Hidrolisis zat makanan pakan oleh enzim cairan rumen sapi asal rumah potong hewan (Hidrolysis of feed nutrient by cow rumen liquid enzymes from slaughterhouse). Agrinak 1:17-24.

Budiansyah, A., Resmi, K. G. Wiryawan, M. T. Soehartono, Y. Widyastuti, \& N. Ramli. 2010. Isolasi dan karakterisasi enzim karbohidrase cairan rumen sapi asal rumah potong hewan. Med. Pet. 33:36-43.

Effiong, M. E., U. L. Unah, G. E. Enyenihi, \& E. K. Ndelekwute. 2019. Dietary effect of feed grade enzymes on growth and digestive physiology of broiler chickens fed rice branbased diet. MOJ Anat. Physiol. 6:74-78.

Gitoee, A., H. Janmohammadi, A. Taghizadeh, \& S. A. Rafat. 2014. Effects of a multi-enzyme on performance and carcass characteristics of broiler chickens fed corn-soybean meal basal diets with different metabolizable energy levels. J. Appl. Anim. Res. 43:295-302. https://doi.org/10.1080/ 09712119.2014.963103

Goli, S. \& H. A. Shahryar. 2015. Effect of enzymes supplementation (Rovabio and Kemin) on some blood biochemical parameters, performance and carcass characterizes in broiler chickens. Iran. J. Appl. Anim. Sci. 5:127-131.

Hajati, H., M. Rezaei, \& H. Sayyahzadeh. 2009. The effects of enzyme supplementation on performance, carcass characteristics and some blood parameters of broilers fed on corn-soybean meal-wheat diets. Int. J. Poult. Sci. 8:11991205. https://doi.org/10.3923/ijps.2009.1199.1205

Han, H. Y., K. Y. Zhang, X. M. Ding, S. P. Bai, Y. H. Luo, J. P. Wang, \& Q. F. Zeng. 2017. Effect of dietary fiber levels on performance, gizzard development, intestinal morphology, and nutrient utilization in meat ducks from 1 to 21 days of age. Poult. Sci. 96:4333-4341. https://doi.org/10.3382/ps/ pex268

Iriyanti, N., B. Hartoyo, \& S. Suhermiyati. 2018. Performance and intestinal profiles of tegal duck fed ration supplemented with prebiotics. Trop. Anim. Sci. J. 41:15-21. https://doi. org/10.5398/tasj.2018.41.1.15

Kang, P., Y. Q. Hou, D. Toms, N. D. Yan, B. Y. Ding, \& J. Gong. 2013. Effects of enzyme complex supplementation to a paddy-based diet on performance and nutrient digestibility of meat-type ducks. Asian-Australas. J. Anim. Sci. 26:253-259. https://doi.org/10.5713/ajas.2012.12479

Krás, R. V., A. M. Kessler, A. M. L. Ribeiro, J. D. I. Henn, I. dos Santos, D. P. Halfen, \& L. Bockor. 2013. Effect of dietary fiber and genetic strain on the performance and energy balance of broiler chickens. Brazil. J. Poult. Sci. 5:15-20. https://doi.org/10.1590/S1516-635X2013000100003

Moftakharzadeh, S. A., H. Moravej, \& M. Shivazad. 2017. Effect of using the Matrix Values for NSP-degrading enzymes on performance, water intake, litter moisture and jejunal digesta viscosity of broilers fed barley-based diet. Acta Sci. - Anim. Sci. 39:65-72. https://doi.org/10.4025/actascianimsci.v39i1.33070

Moss, A. F., P. V. Chrystal, H. H. Truong, S. Y. Liu, \& P. H. Selle. 2017. Effects of phytase inclusions in diets containing ground wheat or $12.5 \%$ whole wheat (pre- and postpellet) and phytase and protease additions, individually and in combination, to diets containing $12.5 \%$ pre-pellet whole wheat on the performance of broiler chickens. Anim. Feed Sci. Technol. 234:139-150. https://doi.org/10.1016/j. anifeedsci.2017.09.007

NRC. 1994. Nutrient Requirements of Poultry. 9th rev.ed. National Academy Press, Washington DC.

Purba, M. \& A. P. Sinurat. 2018. Effect of supplementation of BS4-enzyme levels in rice-bran based rations on performance of growing PMp broiler duck. J. Ilmu Ternak dan Vet. 23:38-44. https://doi.org/10.14334/jitv.v23i1.1669

Rey, M., F. Enjalbert, \& V. Monteils. 2012. Establishment of ruminal enzyme activities and fermentation capacity in dairy calves from birth through weaning. J. Dairy Sci. 95: 1500-1512 http://dx.doi.org/10.3168/jds.2011-4902

Rui, Y., Su, Z. H. Yan-min, A. Wen-jun, N. Rajput, \& W. Tian. 2012. Effect of dietary supplementation of compound enzymes on endogenous digestive enzymes in cherry valley ducks fed miscellaneous meal diet. Pak. J. Zool. 44:1561-1566.

Shahir, M. H., S. Moradi, O. Afsarian, \& O. Esmaeilipour. 2013. Effects of cereal type, enzyme and sodium butyrate addition on growth performance, carcass traits and intestinal 
morphology of broilers. Brazil. J. Poult. Sci. 15:181-189. https://doi.org/10.1590/S1516-635X2013000300003

Steel, R. G. D., \& J. H. Torrie. 1980. Principles and Procedures of Statistic. Translated By: Bambang Sumatri (1989) into Indonesian with the title "Prinsip dan Prosedur Statistika, Suatu Pendekatan Biometrik". PT. Gramedia, Jakarta.

Teymouri, H., H. Zarghi, \& A. Golian. 2018. Evaluation of hullless barley with or without enzyme cocktail in the finisher diets of broiler chickens. J. Agric. Sci. Technol. 20:469-483.

Vaithiyanathan, S., S. Saravanakumar, P. B. Reddy, \& C. Ramakrishna. 2015. Seasonal variation in fibre degrading enzymes activities in the rumen contents of slaughtered sheep, goat and buffalo. Anim. Nutr. Feed Technol. 15: 111-120. http://doi: 10.5958/0974-181X.2015.00012.8

Wang, S. P., W. J. Wang, D. S. Yang, X. L. Zhao, D. M. Luo, \& Y. B. Guo. 2017. Growth, carcass, and physiological traits of growing male China micro-ducks fed various levels of dietary crude fibre. Czech J. Anim. Sci. 62:347-356. https:// doi.org/10.17221/5/2017-CJAS
Wasilewski, R., D. Kokoszyrński, A. Mieczkowska, Z. Bernacki, \& A. Görska. 2015. Structure of the digestive system of ducks depending on sex and genetic background. Acta Vet. Brno 84:153-158. https://doi.org/10.2754/ avb201584020153

Zeng, Q., X. Huang, Y. Luo, X. Ding, S. Bai, J. Wang, Y. Xuan, Z. Su, Y. Liu, \& K. Zhang. 2015. Effects of a multi-enzyme complex on growth performance, nutrient utilization and bone mineralization of meat duck. J. Anim. Sci. Biotechnol. 6:6-13. https://doi.org/10.1186/s40104-015-0013-4

Zhu, H. L., L. L. Hu, Y. Q. Hou, J. Zhang, \& B. Y. Ding. 2014 The effects of enzyme supplementation on performance and digestive parameters of broilers fed corn-soybean diets. Poult. Sci. 93:1704-1712. https://doi.org/10.3382/ ps.2013-03626 